\title{
LITTER DECOMPOSITION AND SOIL NUTRIENTS PRINCE RUPPRECHT'S (LARIX PRINCIPIS-RUPPRECHTII) PLANTATIONS AREA IN SAIHANBA, NORTHERN CHINA
}

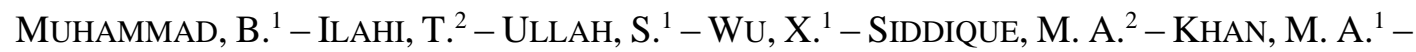 \\ BADSHAH, M. T. ${ }^{1}-$ JIA, Z. ${ }^{*}$ \\ ${ }^{1}$ College of Forestry, Engineering Technology Research Center of Pinus tabuliformis of \\ National Forestry and Grassland Administration, Beijing Forestry University University, No. \\ 35 Qinghua East Road, Haidain District 100083, Beijing, China \\ (e-mails:yousafzaibilal1992@yahoo.com.-B.Muhammad; saifkhan@bjfu.edu.cn-S.Ullah; \\ 1132466807@qq.com-X.Wu; asifkhanbaluch@yahoo.com-M. A. Khan; \\ Badshahgi90@gmail.com-M.T. Badshah) \\ ${ }^{2}$ School of Landscape Architecture, Beijing Forestry University, No. 35 Qinghua East Road, \\ Haidain District 100083, Beijing, China \\ (e-mails:tajdar_2050@yahoo.com-T. Ilahi; muhammad_amir@bjfu.edu.cn-M. A. Siddique) \\ *Corresponding author \\ e-mail: jiazk@bjfu.edu.cn; phone: +86-106-233-7682
}

(Received $11^{\text {th }}$ Dec 2019; accepted $6^{\text {th }}$ May 2020)

\begin{abstract}
Larix principis-rupprechtii (Prince Rupprecht's larch) is a deciduous tree that grows well at high altitudes, sun light and low temperatures. Larix principis-rupprechtii produces a huge quantity of litter, but the rate of litter decomposition is slow compared to coniferous trees. Therefore, we tested different treatments with different concentrations such as External nitrogen $(\mathrm{N})$ source concentrations (Control, $15 \mathrm{~g} \cdot \mathrm{N} \cdot \mathrm{m}^{-2} \mathrm{y}^{-1}, 10$ g.N.m. ${ }^{-2} \cdot \mathrm{y}^{-1}$ and 5 g.N. $\mathrm{m}^{-2} . \mathrm{y}^{-1}$ ), wood vinegar (WV) concentrations as control, 400, 600 and 800 dilutions, thinning intensities (TI) with control, 10\%, 20\% and 30\%, Mix litter (ML) treatment using pure litter of Larix principis-rupprechtii and Betul platyphylla (white birch) with mixing ratios ( PL, PB, 8L:2B, 5L:5B, 7L:3B and 6L:4B) for two consecutive years with six intervals. The results revealed that external WV application with concentration of 400 dilutions improved the litter decomposition (LD) and soil properties. Nitrogen (N) source concentration 10 g.N.m $\mathrm{m}^{-2} . \mathrm{y}^{-1}$ resulted in higher litter decomposition and soil Organic matter (OM) while soil nutrients increased with $\mathrm{N}$ concentration $15 \mathrm{~g} . \mathrm{N} \cdot \mathrm{m}^{-2} . \mathrm{y}^{-1}$. Mix litter treatment (6L:4B) and moderate thinning (20\%) were found best as compared to other concentrations for increasing LD rate and soil properties. Thus, we concluded that the $\mathrm{WV}$ application (400 dilutions) was the best treatment followed by external $\mathrm{N}$ source (10 g.N.m $\left.{ }^{-2} . \mathrm{y}^{-1}\right)$, ML treatment (6L: 4B) and TI (20\%) respectively. Our results conclude that, the present study will help improve the litter decomposition, soil nutrients and soil organic matter under Larix principis-rupprechtii. Keywords: litter decomposition, thinning intensity, wood vinegar $(W V)$, nitrogen $(N)$ source, mix-litter $(M L)$
\end{abstract}

\section{Introduction}

The Larix principis-rupprechtii plantation is mainly found in Northern China. It is the main timber forest in the region, which was planted on a large scale and the plantation area was continuously expanded since 1950. Larix principis-rupprechtii Mayr. is a deciduous tree that grows well under high light and low temperatures (Yuan et al., 2018). This species is mostly used for forestation in warm temperate regions of china, because of its fast growth high-quality wood, resistance to ruthless climate and high wind and improvement in soil conditions (Yuan et al., 2018). Previously, it has been reported that the rate of falling of litter and afterward decomposing play a vital role in nutrient cycling, primary productivity and maintain the soil fertility of forest ecosystem as it acts as input and output system of nutrients (Fioretto et al., 2003; Onyekwelu et al., 2006; Pandey et al., 2007). Forest are 
providing huge quantity of ecosystem services and playing their vital role in carbon, water and nutrient cycling (Polyakova and Billor, 2007; Wang et al., 2017; Li et al., 2019; Farooqi et al., 2020a, b \& c). Organic and inorganic elements for nutrient cycling are mainly provided by litter decomposition that controls nutrient return to the forest ecosystem For a while the decomposition of litter is primarily influenced by the environmental conditions in which decay takes place, the process (slow/fast) of decaying is further dependent by the chemical quality of leaf litter, the nature and abundance of decomposing organisms present (Polyakova and Billor, 2007). The significant effect of external $\mathrm{N}$ availability on litter decay rate was noted by Hobbie (2000), Carreiro et al. (2000) and Hobbie and Vitousek (2000). Sinsabaugh et al. (2002) stated that external $\mathrm{N}$ availability significantly affects microbial decay by the degradation of polysaccharides and polyphenols. This hypothesis is supported by the study of Carreiro et al. (2000), Frey et al. (2004), Sinsabaugh et al. (2002) and Ullah et al. (2019). They stated that that high $\mathrm{N}$ availability increases the activity of cellulolysis and considerably forcibly stop the activity of lignin-degrading enzymes. Another study by Matson et al. (2002) reported that nitrogen addition has an effect on processes and properties of large range of temperate forest ecosystem varying the nutrient cycling of the ecosystem and increasing the soil nutrients.

Silvicultural practices like thinning, tending and pruning have a significant effect on litter decomposition. These practices increase the light availability and air soil temperature resulting changes in nutrient mineralization rates (Kunhamu et al., 2009). Thinning results in changing the soil environment like moisture and temperature of the soil as well as the quality and quantity of litter and further affect the P bioavailability of soil (Hu et al., 2016). Kim et al. (2018) noted that microbial biomass increases as a result of thinning and is associated with $\mathrm{C}$ and $\mathrm{N}$ of soil. Moreover, this effect of thinning is directly related to thinning intensity.

Wood vinegar also is known as pyro ligneous acid, wood distillate or bio-oil is a watersoluble fraction of liquid produced as a result of organic materials pyrolysis. It can act as a biocide for microorganisms, pesticide, and fungicide and can also be used for improving soil nutrients, root and shoot growth as well microbial activity (Baimark and Niamsa, 2009; Steiner et al., 2008; Tiilikkala and Setälä, 2009; Velmurugan et al., 2009; Wei et al., 2009; Yatagai et al., 2002). Wood vinegar is commonly used in Japan for improving fertility of soil (Kadota and Niimi, 2004).

Mix litter is obtained by mixing different leaf litters which have a significant effect on leaf litter nutrients and the surrounding soil micro environment (Mao et al., 2015). Different studies have shown that chemical diversity of litter increase and physical spatial structure of leaf litter is changed as a result of mix litter decomposition, which in turn gives a more appropriate microhabitat and more nutrients to the decomposers which at the end leads to changes in biodiversity and population of the decomposer (Chapman et al., 2013; Liu et al., 2010). The decomposition of mix litter has the ability to change the activity of different types of soil enzymes ( $\mathrm{Li}$ and Liu, 2013). In addition, due to the different substrate quality, controlling of nutrients and decomposition processes of leaf litter, like $\mathrm{N}$ and $\mathrm{P}$, can transferred from nutrient-rich litter to nutrient-poor litter, as a result, the overall leaf litter mixture decomposition is affected (Hättenschwiler et al., 2005).

This present study was carried out to find the effect of different treatments on leaf litter decomposition of Larixprincipis-rupprechtii, soil nutrients and soil organic matter. 


\section{Materials and methods}

\section{Geographical site description}

The present study was intended at Yinhe Forest Farm, the general site of Saihanba Mechanical Forest Farm, Chengde City, Hebei Province, China. Gegraphical location of sampling site with $42^{\circ} 02^{\prime} \sim 42^{\circ} 36^{\prime} \mathrm{N}, 116^{\circ} 51^{\prime} \sim 117^{\circ} 39^{\prime} \mathrm{E}$ (Fig. 1), Elevation of 1650 $\sim 1830 \mathrm{~m}$. This area located in the semi-humid and semi-dry early region. So it belongs to the continental monsoon climate in the cold temperate zone. The annual average temperature is $-1.5{ }^{\circ} \mathrm{C}$. The annual average precipitation and evaporation rate of this area reported about $\sim 530.9 \mathrm{~mm}$ and $\sim 1388 \mathrm{~mm}$ respectively. The main tree species are Larix principis-rupprechtii, Mongolia Scotch pine, Picea asperata and Betula platyphylla. The area covered $\sim 80.74 \%$ by forest.
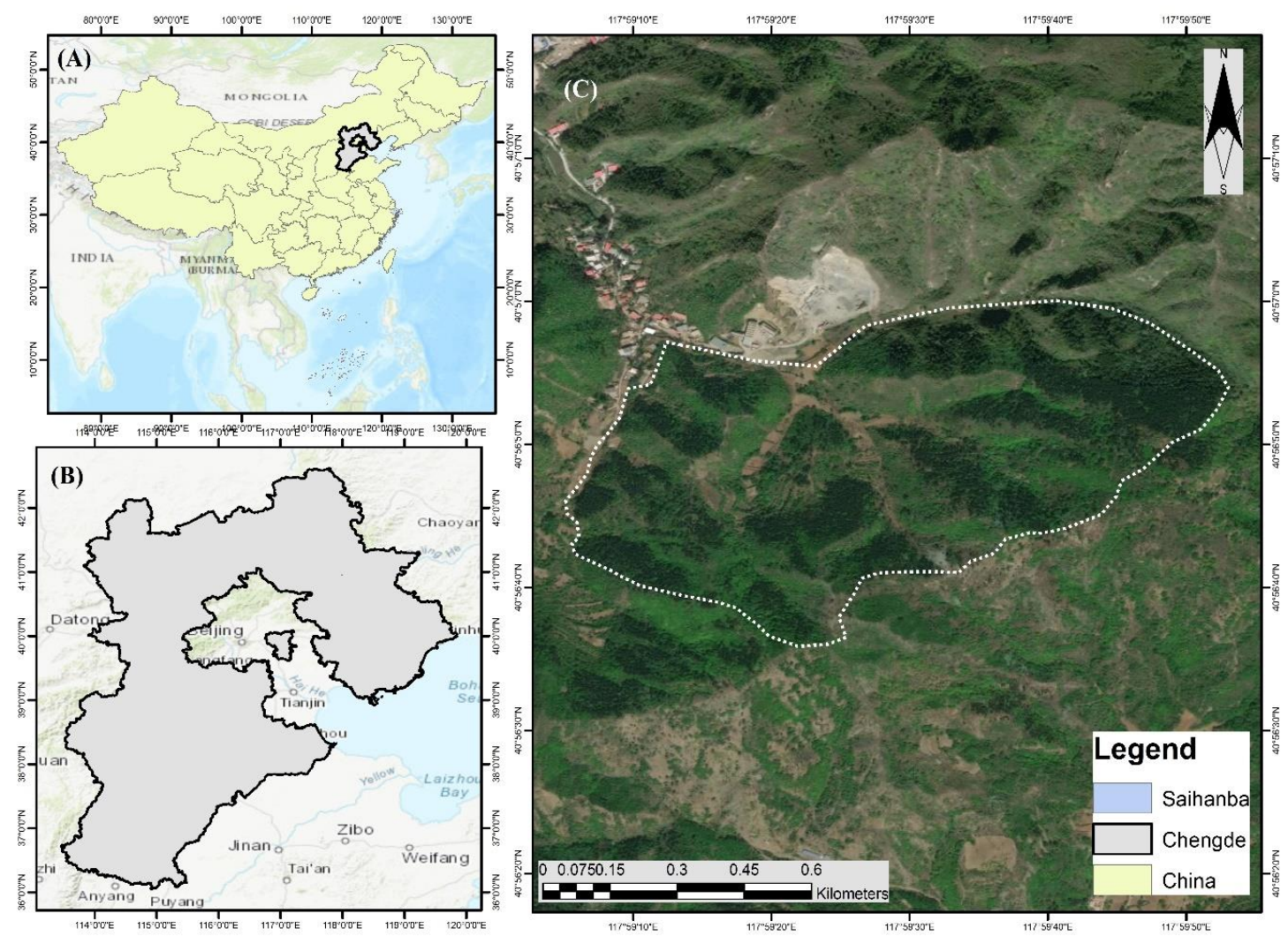

Figure 1. The study area of experiment

In this study, the 22-year-old Larix principis plantation in Saihanba area was selected to find the effect of four different treatments i.e. nitrogen, wood vinegar, thinning intensities and mixed litter (pure Larix principis (PL) and pure Betula platyphylla (PB) on litter decomposition rate and soil nutrients of Larix principis. The experiment of tending and thinning was laid under thinned forest, and the other three treatments (external nitrogen source, external application of wood oxalic liquor, mixed litter) were tested in the un-thinned forest. The treatments used in the study are in Table 1.

Three $20 \mathrm{~m} \times 20 \mathrm{~m}$ repetitive plots were set up for each test treatment, and a total of 54 plots were set up for 18 treatments. The DBH and height of trees in the sample plot 
were measured, and the information of landform, slope, soil condition, elevation and age class of the sample plot were recorded as shown in Table 2.

Table 1. Basic information of stands

\begin{tabular}{c|c|c|c}
\hline $\begin{array}{c}\text { External nitrogen } \\
\text { application }\end{array}$ & $\begin{array}{c}\text { External wood vinegar } \\
\text { application }\end{array}$ & $\begin{array}{c}\text { Thinning } \\
\text { intensities }\end{array}$ & (PL) and (PB) ratio \\
\hline Control $(\mathrm{Ck})$ & Control $(\mathrm{Ck})$ & Control $(\mathrm{Ck})$ & Control Ck) \\
$5 \mathrm{~g} \cdot \mathrm{N} \cdot \mathrm{m}^{-2} \cdot \mathrm{y}^{-1}$ & 400 Dilutions & $15 \%$ & PL (pure Larix principis) \\
$10 \mathrm{~g} \cdot \mathrm{N} \cdot \mathrm{m}^{-2} \cdot \mathrm{y}^{-1}$ & 600 Dilutions & $20 \%$ & PB (pure Betula platyphylla) \\
$15 \mathrm{~g} \cdot \mathrm{N} \cdot \mathrm{m}^{-2} \cdot \mathrm{y}^{-1}$ & 800 Dilutions & $30 \%$ & 5L: 5B, 6L: 4B, 7L: 3B, 8L: 2B \\
\hline
\end{tabular}

Table 2. Basic information of stands

\begin{tabular}{|c|c|c|c|c|c|c|c|c|}
\hline \multirow{2}{*}{$\begin{array}{c}\text { Stand } \\
\text { overview }\end{array}$} & \multicolumn{3}{|c|}{ Site factor } & \multirow{2}{*}{ Age class } & \multirow{2}{*}{$\begin{array}{c}\text { Thinning } \\
\%\end{array}$} & \multirow{2}{*}{$\begin{array}{l}\text { Average } \\
\text { BH/cm }\end{array}$} & \multirow{2}{*}{$\begin{array}{l}\text { Average } \\
\text { tree } H / m\end{array}$} & \multirow{2}{*}{$\begin{array}{c}\text { Density } \\
\text { /hm2 }\end{array}$} \\
\hline & Slope & Soil L & Altitude/m & & & & & \\
\hline 1 & 15 & Thick & 1620 & Middle age $25 \mathrm{a}$ & CK & 10.92 & 11.8 & 2475 \\
\hline 2 & 15 & Thick & 1620 & Middle age $25 \mathrm{a}$ & $15 \%$ & 11.97 & 12.3 & 2150 \\
\hline 3 & 15 & Thick & 1620 & Middle age 25a & $20 \%$ & 12.93 & 12.5 & 2075 \\
\hline 4 & 15 & Thick & 1620 & Middle age $25 \mathrm{a}$ & $30 \%$ & 13.02 & 12.6 & 1800 \\
\hline
\end{tabular}

\section{Litter collection}

Fresh Litter was collected under the 22-year-old Larix principis-rupprechtii and birch forest in the experimental area at the end of April 2015. The litter was collected and dried at $80{ }^{\circ} \mathrm{C}$ in the oven until the weight becomes constant. The litter was weighed and ready for bagging. The dried litter was packed in mesh bags $(20 \mathrm{~cm} \times 10 \mathrm{~cm}$, mesh diameter $1 \mathrm{~mm}$ ) according to the corresponding treatment of each test (Wu et al., 2007). While bagging, the treatments of tending thinning, external wood oxalic liquor and external nitrogen source were all loaded with fresh larch litter, while the mixed litter treatment was packed with each other according to different proportions. Each bag of litter was $20 \mathrm{~g} \pm 0.1 \mathrm{~g}$. The bags were tagged according to the test requirements. Eighteen treatments totaled 1080 bags, including 360 bags for mixed litter treatment and 240 bags for each of the other three treatments. The number of bags in each plot was 60 , 45 were used for sampling, and the remaining 15 were reserved. In May 2015, litter bags were buried in the experimental plots with different treatments. Original litter from the experimental surface layer was removed while burying to bags of litter so that the litter bags and the understory humus layer could contact each other more effectively (Liu, 2013; Che, 2014).

\section{Preparation and application of treatments}

Urea treatments were prepared according to the contents of CK (control), $5 \mathrm{~g} \mathrm{~N} \cdot \mathrm{m}^{-}$ ${ }^{2} \cdot \mathrm{y}^{-1}, 10 \mathrm{~g} \mathrm{~N} \cdot \mathrm{m}^{-2} \cdot \mathrm{y}^{-1}, 15 \mathrm{gN} \cdot \mathrm{m}^{-2} \cdot \mathrm{y}^{-1}$, dissolved in water and fill it in the agricultural sprayer, sprayed on the litter bag in the sample, once every two months. Spraying concentrated liquid of wood vinegar produced by Shijiazhuang Shunqian Carbon Industry Environmental Protection Technology Co., Ltd. The concentrated liquid of the wood vinegar (WV) solution was diluted as blank, diluted 400 times, diluted 600 times, 
and diluted 800 times. In the sample plot, spray it evenly on the litter bag using the agricultural sprayer according to its corresponding treatment, and spray it once every two months. In thinning intensities (TI) treatment the litter bags are properly placed without any treatments and naturally decomposed. In mix litter treatment the bags were filled with mixed and pure litter of Larix principis (PL) and pure Betula platyphylla (PB), buried and decomposed naturally.

\section{Sample collection}

Litter bags were collected in the month of July- September 2015 and May, July and September, 2016. Five samples were collected, and three litter bags were randomly selected each time. The debris on the surface of litter bags must be removed before sampling, in order to ensure that other substances do not affect the measurement results. In the same period, 18 soil samples were sampled in May, July, September 2015 and May, July and September 2016. Typical sampling methods were used in each sample plot. Three sampling points were randomly set up beside the drop bag to remove weeds, such as pine needles, and the soil samples of $0-20 \mathrm{~cm}$ were collected by ring knife.

\section{Analysis}

\section{Residual weight of litter}

The residual weight of litter was determined by taking back the buried litter bag and weighing it to get fresh weight, then weighing it to get dry weight. The oven temperature was adjusted to $80^{\circ} \mathrm{C}$ to be dried at constant temperature and then weighing it. Finally, fresh weight and dry weight were used to calculate litter weight residue rate $(E q$. . $)$.

$$
Y=X t / X o
$$

where $\mathrm{Y}$ represents the residual ratio, $\mathrm{X}_{\mathrm{t}}$ represents the initial amount; and $\mathrm{X}_{0}$ represents the residual amount at the time. Furthermore, for finding the litter decomposition rate, residual rate was subtracted from actual weight of litter.

\section{Nutrient contents and soil organic matter}

The soil sample was crushed first, filtered by 60 mesh sieve, and then classified according to different particle diameters for the determination of nutrient content. The nutrient contents of different soils were determined. Soil total nitrogen and total phosphorus contents of the soil were determined by sulfuric acid-hydrogen peroxide digestion and then measured by AA3 continuous flow analyzer. While the total potassium content of the soil was determined using a flame photometer after desulfurization with sulfuric acid-hydrogen peroxide. Soil organic matter content was determined by using the potassium dichromate-sulfuric acid oxidation method.

\section{Statistical analysis}

The variance analysis was conducted through Statistics 8.1 software, and principle component analysis was used to compare all the data. In addition, the factor analysis 
method is adopted for the comprehensive comparison of each indicator with each index and use SPSS 25 for results visualization.

\section{Results}

\section{Effects of litter decomposition of Larix principis-rupprechtii L. and soil properties under external nitrogen application}

\section{External nitrogen improve litter decomposition rate and soil organic matter}

The application of external nitrogen source improved the litter decomposition rate. The highest litter decomposition rate was observed in nitrogen concentration (10 g.N.m ${ }^{-}$ ${ }^{2} \cdot \mathrm{y}^{-1}$ ), while the least effect was noted in control as evident from Table 3. Which shows that external nitrogen source has the ability to increase the decomposition rate of litter.

Table 3. Effect of external nitrogen source on soil $N, P, K\left(m g g^{-1}\right)$, litter decomposition $(g)$ and organic matter content ( $m g g^{-1}$ )

\begin{tabular}{c|c|c|c|c|c}
\hline \multirow{2}{*}{ Concentrations } & \multicolumn{5}{|c}{ External nitrogen treatment } \\
\cline { 2 - 6 } & $\mathbf{N}\left(\mathbf{m g ~ g}^{-1}\right)$ & $\mathbf{P}\left(\mathbf{m g ~ g}^{-1}\right)$ & $\mathbf{K}\left(\mathbf{m g ~ g}^{-1}\right)$ & $\mathbf{L D} \mathbf{( g )}$ & OMC $\left(\mathbf{m g ~ g}^{-1}\right)$ \\
\hline Control & $9.140 \mathrm{C}$ & $1.675 \mathrm{~B}$ & $3.7598 \mathrm{C}$ & $1.5493 \mathrm{C}$ & $45.758 \mathrm{C}$ \\
$5 \mathrm{~g} . \mathrm{N} \cdot \mathrm{m}^{-2} \cdot \mathrm{y}^{-1}$ & $10.128 \mathrm{~B}$ & $1.8195 \mathrm{~A}$ & $4.502 \mathrm{~B}$ & $2.0081 \mathrm{~B}$ & $49.560 \mathrm{~B}$ \\
$10 \mathrm{~g} . \mathrm{N} \cdot \mathrm{m}^{-2} \cdot \mathrm{y}^{-1}$ & $10.956 \mathrm{~A}$ & $1.5718 \mathrm{C}$ & $4.8482 \mathrm{~A}$ & $2.5209 \mathrm{~A}$ & $53.567 \mathrm{~A}$ \\
$15 \mathrm{~g} \cdot \mathrm{N} \cdot \mathrm{m}^{-2} \cdot \mathrm{y}^{-1}$ & $11.140 \mathrm{~A}$ & $1.4766 \mathrm{D}$ & $5.1111 \mathrm{~A}$ & $1.9898 \mathrm{~B}$ & $48.896 \mathrm{~B}$ \\
\hline
\end{tabular}

Means** with in column sharing same letters are statistically significant at $\mathrm{p} \leq 0.05$. LD in the table represents litter decomposition while organic matter content is denoted by OMC

Application of different concentrations of nitrogen significantly improved the soil organic matter from May 2015 to July 2016, while the highest effect was noted in from May to July 2016 and then started gradual decrease from July to September 2016. The highest effect was noted as a result of nitrogen application concentration 10 g.N.m $\mathrm{m}^{-2} \cdot \mathrm{y}^{-1}$ followed by $15 \mathrm{~g} \cdot \mathrm{N} \cdot \mathrm{m}^{-2} \cdot \mathrm{y}^{-1}$ and $5 \mathrm{~g} \cdot \mathrm{N} \cdot \mathrm{m}^{-2} \cdot \mathrm{y}^{-1}$ respectively. While the lowest effect was observed in control as shown in Table 3. The results were the same as the result of litter decomposition which shows that the more litter decompose the more it increases soil organic matter.

\section{External nitrogen enhances litter and soil nutrients $(N, P, K)$}

Results showed that nitrogen application (ammonium source) to litter significantly increased the soil total nitrogen. Litter treated with external nitrogen source 15 g.N.m ${ }^{-}$ ${ }^{2} \cdot \mathrm{y}^{-1}$ has resulted in higher soil total nitrogen followed by $10 \mathrm{~g} . \mathrm{N} \cdot \mathrm{m}^{-2} \cdot \mathrm{y}^{-1}$ and $5 \mathrm{~g} \cdot \mathrm{N} \cdot \mathrm{m}^{-2} \cdot \mathrm{y}^{-}$ 1 respectively. The lowest soil nitrogen was distinguished in an untreated litter (Table 3). The total nitrogen content increased slowly; from July to September, but later it declined; from September 2015 to May of the next year then again it increased rapidly; from May to July 2016 and then started falling rapidly from July to September in 2016.The rapid increase in nitrogen content from May to July 2016 may be due to temperature rise and rain which resulted in increased microbial activity and soil water content, which resulted in higher soil nitrogen. 
Soil phosphorus content was also significantly affected as a result of nitrogen application. Nitrogen source $5 \mathrm{~g} . \mathrm{N} \cdot \mathrm{m}^{-2} \cdot \mathrm{y}^{-1}$ was noted to have highest phosphorus content followed by control. Nitrogen concentration $15 \mathrm{~g} \cdot \mathrm{N} \cdot \mathrm{m}^{-2} \cdot \mathrm{y}^{-1}$ has noted to have the least nitrogen content followed by nitrogen litter treated with 10 g.N. $\mathrm{m}^{-2} \cdot \mathrm{y}^{-1}$. As evidence from results phosphorous has adverse effects as a result of nitrogen application. Data regarding nitrogen effect on soil total phosphorous is shown in Table 3 and Figure 2.

Likewise, the increase was noted in soil total potassium as a result of nitrogen application to litter from May to July 2015 while from July 2015 to May 2016 there was a decrease in potassium content (Table 3.) it may be due to litter accumulation because soil potassium is being transferred. From May-September 2016, it was first rising and then falling, which was related to nutrient cycling of litter, temperature, and rainfall. In general nitrogen has direct effect on soil total potassium content.

A Nitrogen $(\mathrm{N})$

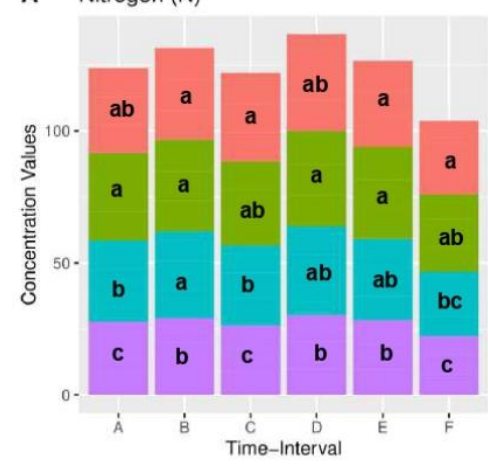

D Litter Decomposition (LD)

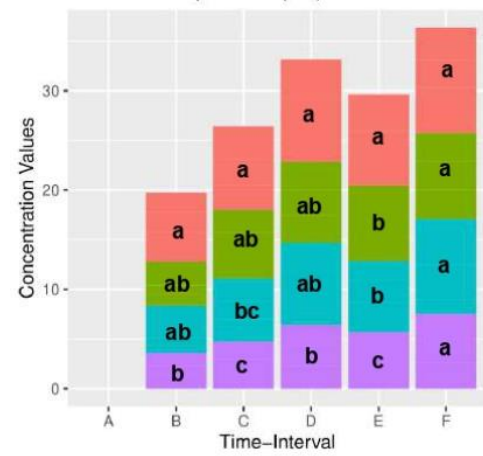

B Phosphorus (P)

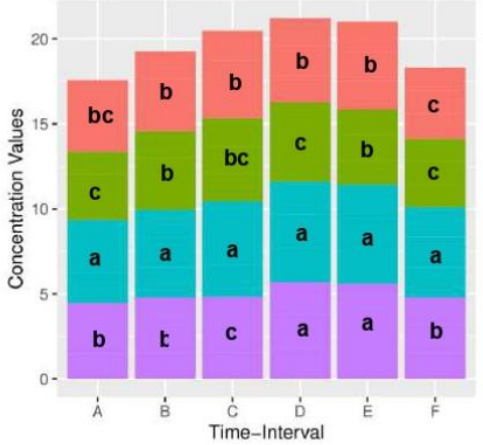

E Organic Matter (OM)

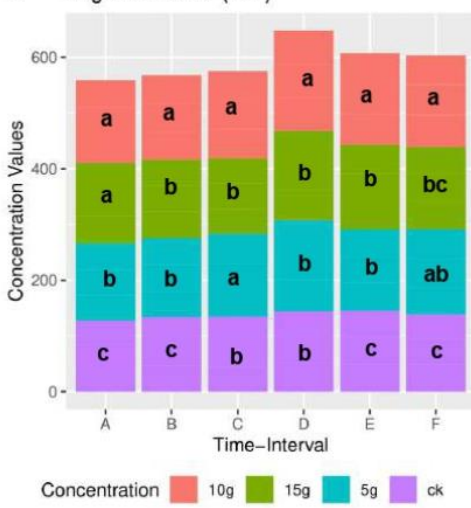

C Potassium (K)

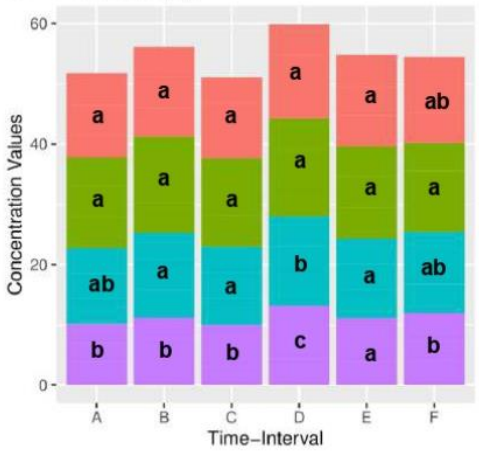

Figure 2. Effect of external nitrogen application (ammonia source) on litter decomposition and soil properties. $A, B, C, D, E$, and $F$ in the figure shows different months for data collection for two consecutive years which are May 2015, July 2015 September

\section{Effects of litter decomposition of Larix principis-rupprechtii L. and soil properties under external wood vinegar application}

Wood vinegar have obvious effect on litter decomposition rate and soil organic matter

Wood vinegar application significantly increased the decomposition rate of the litter as compared to control. The maximum decomposition rate was noted in wood vinegar with 400 dilutions followed by 600 and 800 dilutions respectively. The lowest decomposition rate was noted in control as evidence from Table 4. 
Data regarding soil organic content as shown in Table 4 show that wood vinegar diluted 400 times has the highest effect on soil organic matter followed by 600 dilutions and 800 dilutions respectively. Soil organic matter was significantly improved by external wood vinegar application to the litter as compared to the control or untreated.

\section{Wood vinegar not only effect litter but have significant effect on soil nutrients $(N, P, K)$}

At the end of the experiment, the total nitrogen content of the soil from the largest to the smallest is diluted 400 times $>600$ times diluted $>\mathrm{CK}>800$ times diluted as evident from Table 4. It can be seen that the total nitrogen content of the soil will be affected by the external application of wood vinegar. The best dilution factor is 400 , with the decrease of the concentration of wood vinegar; the accumulation of nitrogen in the soil is no longer accelerated and is inhibited. Lower the concentration, the more significant the inhibition. From May to July 2015, the total nitrogen content of the soil gradually increased and from July to September and started decreasing from September 2015 to May of the next year, except for the dilution of 800 times, there has been a decrease; In the same year, the rapid increase in May-July, the reason for this change may be due to the snowmelt in the previous season and the increase in precipitation during the season, which shows in Figure 3.
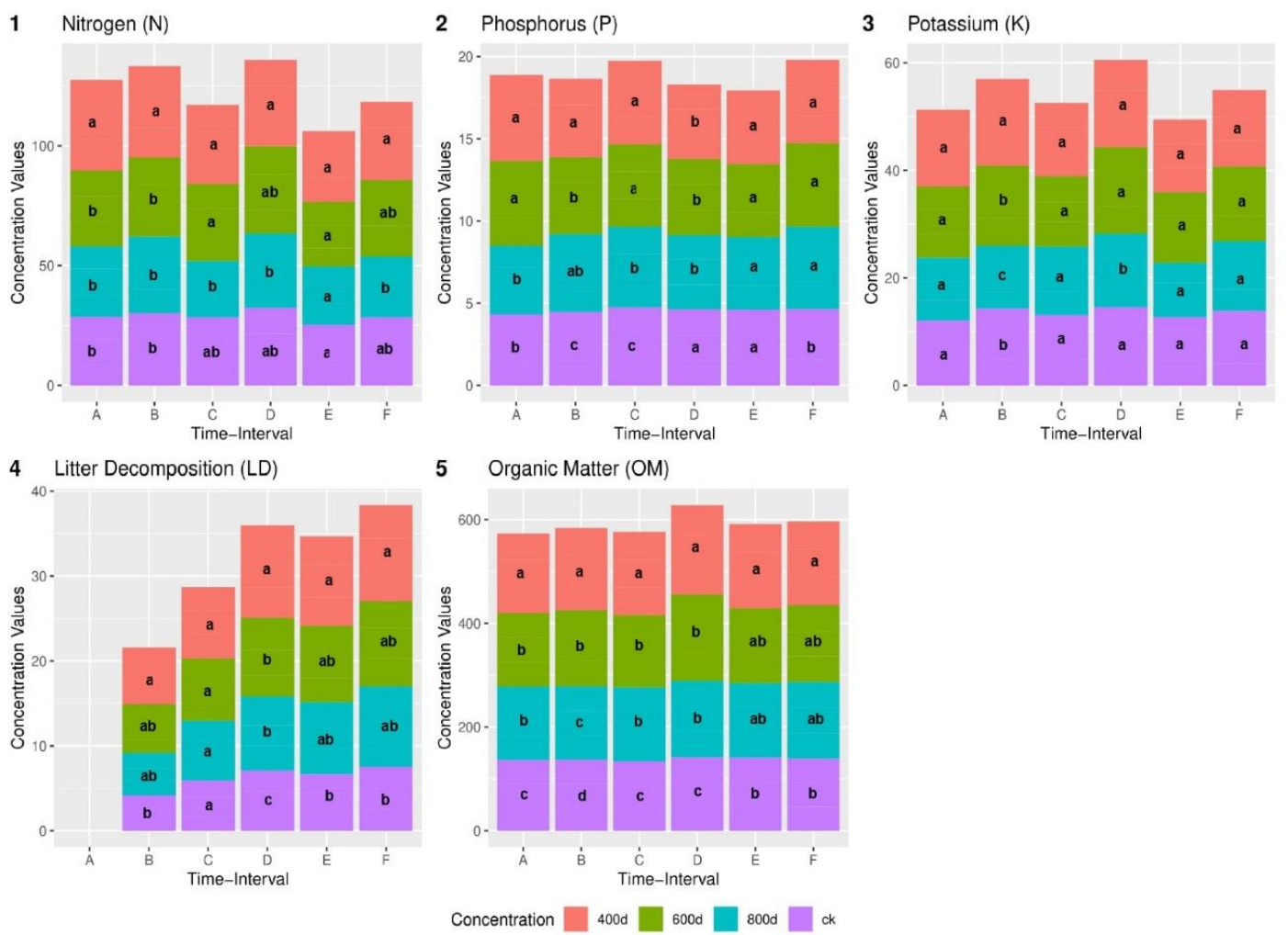

Figure 3. Effect of wood vinegar application on litter decomposition and soil properties. A, B, $C, D, E$, and $F$ in the figure shows different months for data collection for two consecutive years which are May 2015, July 2015 September 2015, May 2016, July

The total phosphorus content of soil as a result of external wood vinegar was significantly increased as compared to control group. At the end of experiment, External 
wood vinegar treatment with 400 dilutions has the highest phosphorus content followed by 600 times dilution and 1000 times dilution respectively. The control group has the lowest phosphorous content as shown in Table 4 indicating that wood vinegar application increases the soil phosphorous content. Continuous rise in May-September 2015, followed by a slight decline from September 2015 to May 2016, the reasons may be related to temperature changes; it continued to rise from May to September 2016.

The effect of different wood vinegar concentrations on the soil total potassium content was significantly different, indicating that the external application of wood vinegar had a certain degree of influence on the total potassium content of the litter under Larix principis-rupprechtii. At the end of the experiment, the total potassium content in the soil was sorted as follows: dilution 400 times $>$ dilution 600 times $>$ CK > dilution 800 times (Table 4). The total potassium content of the soil increased from May to July 2015 and then decreased again in September; in 2016.

Table 4. Effect of wood vinegar on soil $N, P, K\left(\mathrm{mg} \mathrm{g}^{-1}\right)$, litter decomposition ( $\left.\mathrm{g}\right)$ and organic matter content $\left(\mathrm{mg} \mathrm{g}^{-1}\right)$

\begin{tabular}{c|c|c|c|c|c}
\hline \multirow{2}{*}{ Concentrations } & \multicolumn{5}{|c}{ External Nitrogen treatment } \\
\cline { 2 - 6 } & $\mathbf{N}\left(\mathbf{m g ~ g}^{-\mathbf{1}}\right)$ & $\mathbf{P}\left(\mathbf{m g ~ g}^{-\mathbf{1}}\right)$ & $\mathbf{K}\left(\mathbf{m g ~ g}^{\mathbf{- 1}}\right)$ & $\mathbf{L D} \mathbf{( g )}$ & $\left.\mathbf{O M C ~} \mathbf{m g ~ g}^{-\mathbf{1}}\right)$ \\
\hline $\mathrm{CK}$ & $9.640 \mathrm{C}$ & $1.5238 \mathrm{~B}$ & $4.4899 \mathrm{~B}$ & $1.7437 \mathrm{C}$ & $46.099 \mathrm{D}$ \\
$400 \mathrm{~d}$ & $11.491 \mathrm{~A}$ & $1.6161 \mathrm{~A}$ & $4.8753 \mathrm{~A}$ & $2.6559 \mathrm{~A}$ & $53.733 \mathrm{~A}$ \\
$600 \mathrm{~d}$ & $10.676 \mathrm{~B}$ & $1.6121 \mathrm{~A}$ & $4.6874 \mathrm{AB}$ & $2.2963 \mathrm{~B}$ & $49.306 \mathrm{~B}$ \\
$800 \mathrm{~d}$ & $9.214 \mathrm{C}$ & $1.5424 \mathrm{~B}$ & $4.0403 \mathrm{C}$ & $2.1513 \mathrm{~B}$ & $48.086 \mathrm{C}$ \\
\hline
\end{tabular}

Means** with in column sharing same letters are statistically significant at $\mathrm{p} \leq 0.05$. LD in the table represents litter decomposition while organic matter content is denoted by OMC

\section{Effects of litter decomposition of Larix principis-rupprechtii L. and soil properties under different thinning intensities}

\section{Thinning intensities effect on Litter decomposition rate and soil organic matter}

Thinning intensities shows the data regarding litter decomposition as a result of different thinning intensities (Table 5). It is evident from Table 3 that decomposition rate was higher in control which were un-thinned trees followed by the trees which have thinning intensities of $30 \%$. The least residues noted in $20 \%$ thinning intensities followed by $10 \%$. This means that thinning intensities with $20 \%$ was the best treatment for litter decomposition.

Table 5. Effect of different thinning intensity on soil $N, P, K\left(m g g^{-1}\right)$, litter decomposition $(g)$ and organic matter content $\left(m g g^{-1}\right)$

\begin{tabular}{|c|c|c|c|c|c|}
\hline \multirow{2}{*}{ Concentrations } & \multicolumn{5}{|c|}{ External nitrogen treatment } \\
\hline & $\left.\operatorname{Nmg~g}^{-1}\right)$ & $P\left(\mathrm{mg} \mathrm{g}^{-1}\right)$ & $K\left(\mathrm{mg} \mathrm{g}^{-1}\right)$ & LD (g) & OMC $\left(\mathrm{mg} \mathrm{g}^{-1}\right)$ \\
\hline CK & 8.607D & $1.5303 \mathrm{~B}$ & 4.7330B & $1.1298 \mathrm{C}$ & 44.419D \\
\hline $10 \%$ & $9.422 \mathrm{C}$ & $1.5526 \mathrm{AB}$ & $4.8864 \mathrm{AB}$ & $1.7911 \mathrm{~B}$ & $48.321 \mathrm{C}$ \\
\hline $20 \%$ & $10.459 \mathrm{~A}$ & $1.5562 \mathrm{~A}$ & $4.9750 \mathrm{~A}$ & $2.3944 \mathrm{~A}$ & $52.406 \mathrm{~A}$ \\
\hline $30 \%$ & $9.908 \mathrm{~B}$ & $1.5393 \mathrm{AB}$ & $4.8459 \mathrm{AB}$ & $2.1959 \mathrm{~A}$ & $50.990 \mathrm{~B}$ \\
\hline
\end{tabular}

Means** with in column sharing same letters are statistically significant at $p \leq 0.05$. LD in the table represents litter decomposition while organic matter content is denoted by OMC 
At the end of the experiment, the soil total organic content was significantly increased by thinning. The highest total organic content was noted as a result of $20 \%$ thinning followed by $30 \%$ and $10 \%$ respectively. The lowest organic content was noted as a result of un-thinned tress. The overall trend of soil organic matter content under the different thinning intensity of Larix principis-rupprechtii is influenced and changes with seasonal changes, which is as follows: from May to July 2015, the overall increase; from July to September 2015, except for the thinning intensity of $30 \%$. The content of organic matter decreased in other tending thinning; from September 2015 to May of the next year, it increased rapidly from May to September of the following year, it slowly declined (Table 5 and Fig. 4).

\section{Thinning intensities effect on soil nutrients $(N, P, K)$}

Nitrogen content increased from May to September 2015 as a result of thinning intensities, and the increase was the fastest when the thinning intensity was $20 \%$ from September 2015 to May of the following year. It increased again in July 2016, but in up to September of the same year, it slowly declined. There were significant differences in soil total nitrogen content under the different thinning intensity of Larix principisrupprechtii litter decomposition. The highest nitrogen content was noted as a result of thinning intensity $20 \%$ followed by $30 \%$ and $10 \%$ respectively as shown in Table 5 . Lowest nitrogen content was noted as a result control or un-thinned tress which shows in Figure 4.
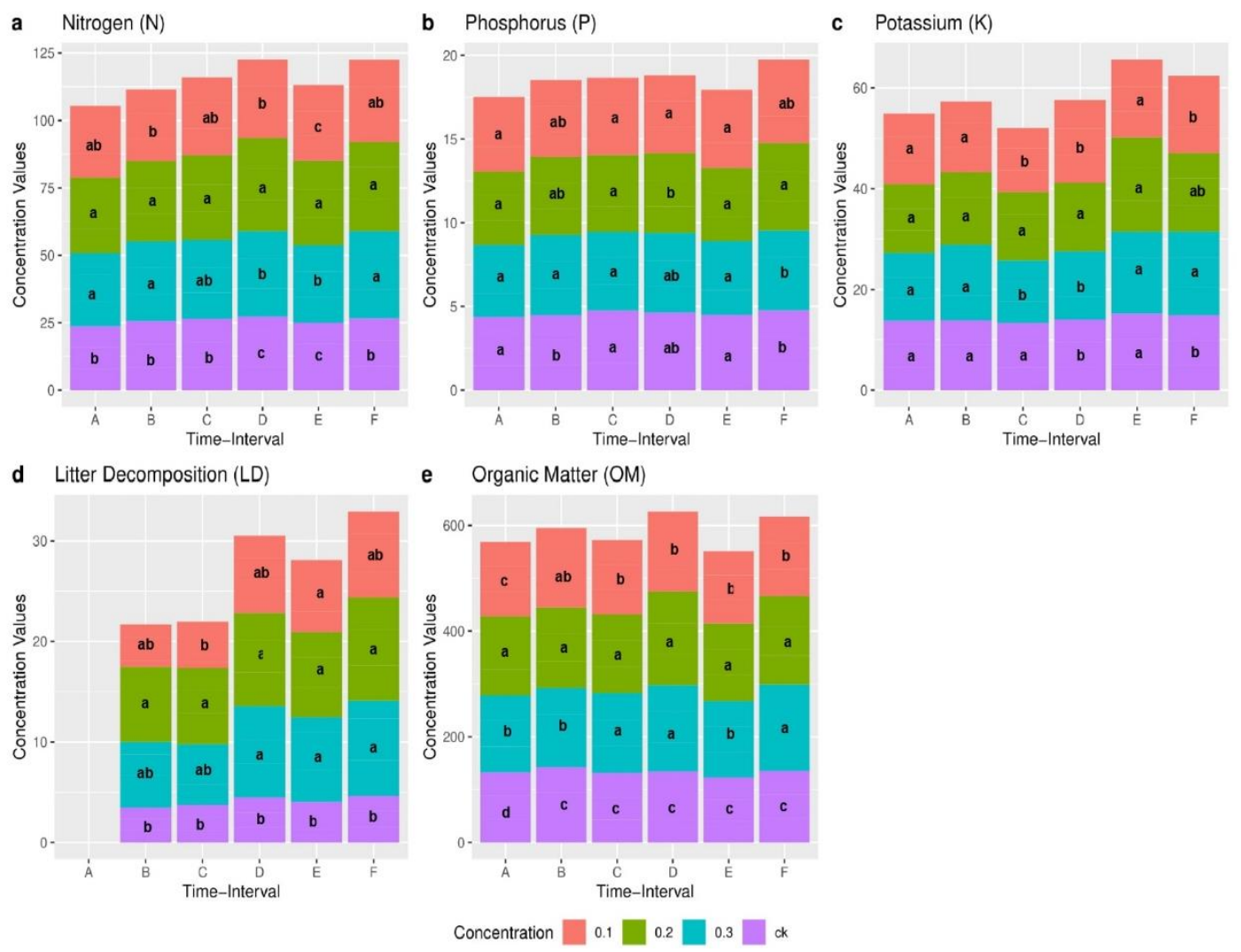

Figure 4. Effect of different Thinning intensities on litter decomposition and soil properties. A, $B, C, D, E$, and $F$ in the figure shows different months for data collection for two consecutive years which are May 2015, July 2015 September 2015, May 2016 
The total phosphorus content of soil with different thinning intensity showed a gradual increasing change. At the end of the experiment maximum soil total phosphorus content was noted in $20 \%$ thinning followed by $15 \%$ thinning and $30 \%$ thinning respectively. The lowest total phosphorous was noted in control (Table 5).

The total potassium content of the soil with different thinning intensity increased first and then decreased. When the thinning intensity is $20 \%$, the soil potassium content in the forest increased rapidly from September 15 to June, which may be related to snow accumulation.

\section{Effects of litter decomposition of Larix principis-rupprechtii L. and soil properties under different Mix litter ratios}

Mix litter (pure Larix principis $(P L)$ and pure Betula platyphylla $(P B)$ effect on litter decomposition rate and soil organic matter

The decomposition rate of two pure litters was slower as compared to mixed litter ratios as evident from Table 6. All the mixed litter ratios showed to have best result than pure. The highest decomposition rate of litter was noted in $8 \mathrm{~L}: 2 \mathrm{~B}$ followed by $5 \mathrm{~L}: 5 \mathrm{~B}$, 7L: 3B and 6L: 4B respectively. Check it which is best, mixed or pure or how much which one, draw fine conclusion.

Table 6. Effect of mix letter application on soil $N, P, K\left(\mathrm{mg} \mathrm{g}^{-1}\right)$, litter decomposition $(\mathrm{g})$ and organic matter content $\left(\mathrm{mg} \mathrm{g}^{-1}\right)$

\begin{tabular}{c|c|c|c|c|c}
\hline \multirow{2}{*}{ Concentrations } & \multicolumn{5}{|c}{ External nitrogen treatment } \\
\cline { 2 - 6 } & N (mg g-1) & P (mg g-1) & K (mg g-1) & LD $(\mathbf{g})$ & \multicolumn{1}{|c}{ OMC $\left(\mathbf{m g ~ g}^{-\mathbf{1}}\right)$} \\
\hline B & $9.570 \mathrm{C}$ & $1.5715 \mathrm{D}$ & $4.7295 \mathrm{~B}$ & $0.0000 \mathrm{~F}$ & $44.262 \mathrm{E}$ \\
L & $8.782 \mathrm{D}$ & $1.5047 \mathrm{E}$ & $4.6727 \mathrm{~B}$ & $2.5383 \mathrm{E}$ & $46.215 \mathrm{D}$ \\
6L: 4B & $10.571 \mathrm{~A}$ & $1.8534 \mathrm{~A}$ & $4.9832 \mathrm{~A}$ & $2.9574 \mathrm{D}$ & $52.410 \mathrm{~A}$ \\
7L: 3B & $10.167 \mathrm{~B}$ & $1.7036 \mathrm{~B}$ & $4.7400 \mathrm{~B}$ & $3.5327 \mathrm{C}$ & $50.250 \mathrm{~B}$ \\
5L: 5B & $9.885 \mathrm{BC}$ & $1.6204 \mathrm{C}$ & $4.7321 \mathrm{~B}$ & $3.8217 \mathrm{~B}$ & $48.230 \mathrm{C}$ \\
8L: 2B & $9.673 \mathrm{C}$ & $1.5751 \mathrm{D}$ & $4.7408 \mathrm{~B}$ & $4.5406 \mathrm{~A}$ & $49.988 \mathrm{~B}$ \\
\hline
\end{tabular}

Means** with in column sharing same letters are statistically significant at $p \leq 0.05$. LD in the table represents litter decomposition while organic matter content is denoted by OMC

The soil organic matter content of Larix principis-rupprechtii under different mixing ratios is increasing continuously, as shown in Table 3 At the end of experiment the maximum organic matter content was noted as $6 \mathrm{~L}: 4 \mathrm{~B}>7 \mathrm{~L}: 3 \mathrm{~B}>8 \mathrm{~L}: 2 \mathrm{~B}>5 \mathrm{~L}$ : $5 \mathrm{~B}>\mathrm{PL}>\mathrm{PB}$.

Mix litter of pure Larix principis (PL) and Betula platyphylla (PB) effect on soil nutrients $(N, P, K)$

The soil total nitrogen content of pure Betula platyphylla was higher than pure Larix principis (PL) because of the higher decomposition rate of pure Betula platyphylla (PB) than pure Larix principis (PL). Mix litter ratios had however more nitrogen contents noted than pure litter. At the end of the experiment the highest soil nitrogen observed in 6L: 4B followed by 7L: 3B, 5L: 5B and 8L: 2B respectively as evident from Table 6 and Figure 5. 

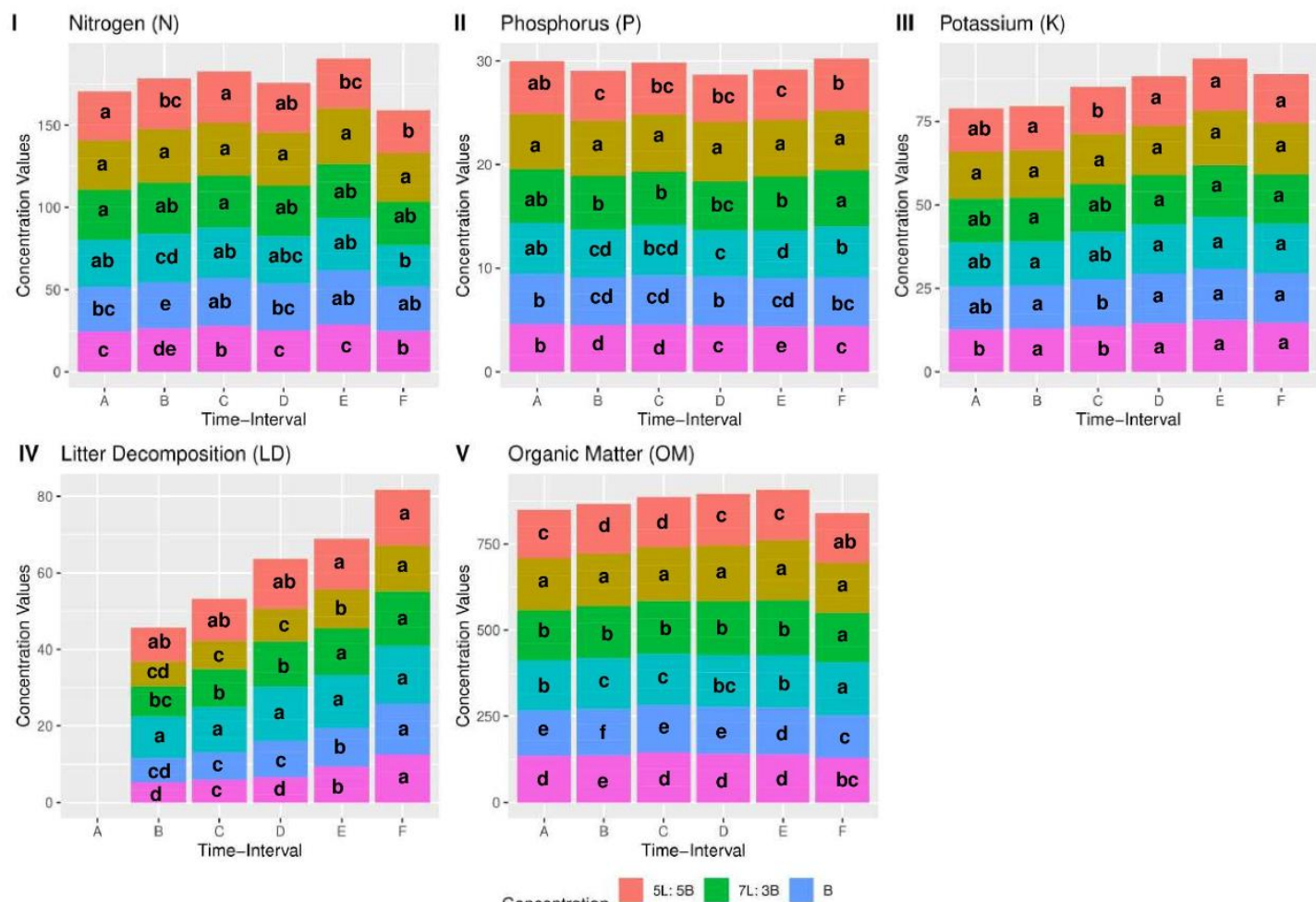

Figure 5. Effect of different mix litter application on litter decomposition and soil properties. A, $B, C, D, E$, and $F$ in the figure shows different months for data collection for two consecutive years which are May 2015, July 2015 September 2015, May 20

The total phosphorus content of the soil under different mixed proportions of Larix principis-rupprechtii showed an increasing trend. By the end of the experiment, the total phosphorus content of the soil under mixed treatment was $6 \mathrm{~L}$ : $4 \mathrm{~B}>5 \mathrm{~L}: 5 \mathrm{~B}>7 \mathrm{~L}$ : 3B > 8L: 2B (Table 6). 6L: 4B increased the total phosphorus in the soil most.

Soil total potassium content was increased as a result of mix litter application but the change with in different mix litter application was non-significant as shown in Table 6 mix litter has no significant effect on soil total potassium.

\section{Integrated score sorting for litter decomposition of Larix principis-rupprechtii L. and soil properties}

The data regarding the best treatments for litter decomposition of Larix principisrupprechtii L. and soil properties can be seen from the integrated score sorting of different treatments and total variance. External wood vinegar application (400 dilutions) stands first in the row followed by external nitrogen application $\left(10 \mathrm{~g} \cdot \mathrm{N} \cdot \mathrm{m}^{-2} \cdot \mathrm{y}^{-1}\right)$, mixed litter (6L: 4B) and thinning (20\%) respectively as shown in Table 7.

\section{Principal component analysis}

The evaluation of four treatment and to provide a comprehensive analysis, the principal component analysis was performed for whole treatment. The variance and variance cumulative rate of each component is shown in Table 8. SPSS extracted two 
components along with their eigenvalues. The cumulative contribution of the three principal components is $95.819 \%$

Table 7. The integrated score sorting of different treatments

\begin{tabular}{c|c|c|c|c|c}
\hline Treatments & F1 & F2 & F3 & Integrated score & Ranking \\
\hline Wood vinegar application (400 d) & 1.47151 & -0.1744 & -0.23293 & 0.627808 & 1 \\
External nitrogen source (10g/m-2/y-1) & -0.38423 & 1.42391 & -0.27359 & 0.126706 & 2 \\
Mixed-litter (6L: 4B) & -0.3246 & -0.34065 & 1.42429 & 0.083974 & 3 \\
Thinning intensity (20\%) & -0.76268 & -0.90886 & -0.91777 & -0.83849 & 4 \\
\hline
\end{tabular}

Table 8. Total variance explained and extraction method: principal component analysis

\begin{tabular}{c|c|c|c|c|c|c|c|c|c}
\hline \multirow{2}{*}{ Components } & \multicolumn{3}{|c|}{ Initial eigenvalues } & \multicolumn{3}{c|}{$\begin{array}{c}\text { Extraction sums of squared } \\
\text { loadings }\end{array}$} & \multicolumn{2}{c}{ Rotation sums of squared loadings } \\
\cline { 2 - 9 } & Total & $\begin{array}{c}\text { \% of } \\
\text { variance }\end{array}$ & $\begin{array}{c}\text { Cumulative } \\
\text { \% }\end{array}$ & Total & $\begin{array}{c}\text { \% of } \\
\text { variance }\end{array}$ & $\begin{array}{c}\text { Cumulative } \\
\text { \% }\end{array}$ & Total & $\begin{array}{c}\text { \% of } \\
\text { variance }\end{array}$ & $\begin{array}{c}\text { Cumulative } \\
\text { \% }\end{array}$ \\
\hline 1 & 3.726 & 74.523 & 74.523 & 3.726 & 74.523 & 74.523 & 2.479 & 49.579 & 49.579 \\
2 & 1.065 & 21.296 & 95.819 & 1.065 & 21.296 & 95.819 & 1.341 & 26.813 & 76.392 \\
3 & .209 & 4.181 & 100.000 & .209 & 4.181 & 100.000 & 1.180 & 23.608 & 100.000 \\
4 & $2.299 \mathrm{E}-16$ & $4.597 \mathrm{E}-15$ & 100.000 & & & & & & \\
5 & $3.772 \mathrm{E}-17$ & $7.544 \mathrm{E}-16$ & 100.000 & & & & & & \\
\hline
\end{tabular}

\section{Discussion}

Nitrogen source has an effect on litter decomposition at the early stages of decomposition which is later decreased due to higher lignin rate (Berg and Staaf, 1980). Litter decomposition has a vital role in nutrients cycling, transformation of materials and circulation of carbon and nitrogen in the ecosystem (Handa et al., 2014). Our study is in line with the study of Hobbie (2000) and Vestgarden (2001) who also noted the positive effect of nitrogen application on litter decomposition. This may be due to the fact that leaf litter having increased nitrogen is more favorable for both bacteria and fungi due to which it decomposes quickly (Aerts, 1997; Swift et al., 1979). N fertilization externally to litter increased the decomposition rate at two sites (Hobbie, 2005). An increase in soil organic content and soil nutrients may be due to higher decomposition rate of litter as a result of different treatments as described by Aerts (1997), Ahmad et al. (2018) and Swift et al. (1979) who stated that increase in litter decomposition results in higher soil organic matters and higher soil nutrients. Liu et al. (2013) stated that $\mathrm{N}$ application increases the soil nitrogen and $\mathrm{N}$ cycling which accelerates the decomposition rate of litter as a result soil nutrients and organic matter content is increased. Rapid decrease and increase in soil total nitrogen content in the study may be due to temperature rise and rain which resulted in increased microbial activity and soil water content which resulted in higher soil nitrogen. The two main processes which regulates the $\mathrm{C}$ cycling are plant litter decomposition and soil respiration.

Wood vinegar some concentrations were found to increase the activity of some enzymes (Koc et al., 2018). Wood vinegar is being commonly used in Japan for soil fertility and has significant effect on improving soil fertility (Kadota and Niimi, 2004). Jeong et al. (2015) stated that wood vinegar significantly improved the soil nutrients and soil chemical properties, therefore, the increased nutrients especially $\mathrm{N}$ increase can 
be the reason for litter decomposition. Burnette (2010) stated that one of the most important uses of wood vinegar is improving soil quality. Our study is in line with the study of Jeong et al. (2015) who also noted that soil nutrients are improved as a result of wood vinegar application. We can conclude from the results that increased soil nutrients may be the reason for increased litter decomposition.

Thinning has been noted to have a positive effect on litter decomposition and forest productivity (Hoorens et al., 2010). It is reported (Hu et al., 2016) that thinning has an effect on leaf litter nutrients such as it increases the nitrogen content of the soil. Higher the soil N content results in more decomposition of litter (Pandey et al., 2007) also stated that thinning changes the overall canopy of the trees which results in change of microclimatic condition of the soil (i.e. uprising the temperature and moisture of the soil), These changes in soil conditions due to thinning results in higher decomposition of litter and nutrient cycling (Hoorens et al., 2010; Osono et al., 2003; Prescott, 2002; Ruano et al., 2013), however structural chemistry of litter can be affected as a result of high thinning intensities and increased biomass lead to lower tissue concentrations resulting in lower nutrients concentration which in turn lower the decomposition of leaf litter (Kunhamu et al., 2009). Nitrogen, phosphorous and lignin concentrations increase with the litter decomposition however potassium contents decrease regardless of thinning (Kunhamu et al., 2009). Our results are the same as Tian et al. (2019) who stated that higher P availability was reported in Larix principis as a result of moderate thinning.

Mix litter regularly increases the mass loss and had more nutrient concentration as compared to single litter, more soil nutrients mean less nutrient loss, mix litter can import nutrients from the surrounding litter and soil during decomposition (Gartner and Cardon, 2004). Mix litter has an increasing effect on decomposition in comparison to litter applied alone and have significant effect on nutrients content, abundant decomposers, and decomposition. During litter decomposition the microenvironment of mix litter decomposition is different from single litter decomposition environment (Chen et al., 2011; Liu et al., 2006). Mix litter significantly affects nutrient dynamics especially the $\mathrm{P}$ content (Chen et al., 2011). Mix litter results in more accurate litter decomposition and biogeochemical cycle ( $\mathrm{Li}$ et al., 2016). The increase rate of litter decomposition may be due to the increase in soil nutrients especially $\mathrm{N}$ content which results in more litter decomposition and organic contents.

\section{Conclusion}

All the treatments improved leaf litter decomposition of Larix principis and enhanced the soil nutrients and soil organic contents. External wood vinegar application (400 dilutions), External nitrogen application $\left(10 \mathrm{~g} \cdot \mathrm{N} \cdot \mathrm{m}^{-2} \cdot \mathrm{y}^{-1}\right)$, Mixed litter $(6 \mathrm{~L}: 4 \mathrm{~B})$ and Thinning (20\%) are the best concentrations. While wood vinegar application with 400 dilutions is the best treatment for litter decomposition, increasing soil nutrients and soil organic contents followed by External nitrogen application $\left(10 \mathrm{~g} \cdot \mathrm{N} \cdot \mathrm{m}^{-2} \cdot \mathrm{y}^{-1}\right)$, Mixed litter (6L:4B) and Thinning (20\%) respectively. In future more combinations with various concentrations or other substance can be helpful to expand the area of litter decomposition of this species as well as other related species.

Acknowledgements. The authors would like to express their gratitude to all the contributed academic members for their constant support and sharing their skills. We are also thankful to the research team, Referees and Dr Adnan Ahmad and Dr Tauheed Ullah Marwat for guidance and timely suggestions. 
Finally, we would also like to thank the funding agency "effects of spatial variability and biological factors on trunk respiration of Larix principis-rupprechtii and its internal mechanism" Grant No. (31870387) 2019.01-2022.12" to make this study successful.

Conflict of interests. The authors declare that they have no conflict of interests.

Data availability. The data [doc file, excel sheet] used to support the finding of this study are available from the corresponding author upon request.

\section{REFERENCES}

[1] Aerts, R. (1997): Climate, leaf litter chemistry and leaf litter decomposition in terrestrial ecosystems. - Oikos 79: 439-449.

[2] Ahmad, A., Liu, Q.-J., Nizami, S., Mannan, A., Saeed, S. (2018): Carbon emission from deforestation, forest degradation and wood harvest in the temperate region of Hindukush Himalaya, Pakistan between 1994 and 2016. - Land Use Policy 78: 781-790.

[3] Baimark, Y., Niamsa, N. (2009): Study on wood vinegars for use as coagulating and antifungal agents on the production of natural rubber sheets. - Biomass and Bioenergy 33(6-7): 994-998.

[4] Berg, B., Staaf, H. (1980): Decomposition rate and chemical changes of Scots pine needle litter. II. Influence of chemical composition. - Ecological Bulletins 32: 373-390.

[5] Burnette, R. (2010): An introduction to wood vinegar. - ECHO Asia Regional Office. http://c. ymcdn. com/sites/www.echocommunity.org (accessed February 13, 2013).

[6] Carreiro, M., Sinsabaugh, R., Repert, D., Parkhurst, D. (2000): Microbial enzyme shifts explain litter decay responses to simulated nitrogen deposition. - Ecology 81(9): 23592365.

[7] Chapman, S. K., Newman, G. S., Hart, S. C., Schweitzer, J. A., Koch, G. W. (2013): Leaf litter mixtures alter microbial community development: mechanisms for non-additive effects in litter decomposition. - PLoS One 8(4): e62671.

[8] Che, Y. (2014): Study on the Tending Technology of Larix Principis-Rupprechtii Plantation Forest in Saihanba. - Beijing Forestry University, Beijing.

[9] Chen, J., Li, Y., Huang, J. (2011): Decomposition of mixed litter of four dominant species in an Inner Mongolia steppe. - Chinese Journal of Plant Ecology 35(1): 9-16.

[10] Farooqi, T.J.A., Abbas, H., and Hussain, S. (2020a): The hydrological influence of forest harvesting intensity on streams: a global synthesis with implications for policy. - Applied Ecology and Environmental Research, ISSN 17850037 (In press).

[11] Frooqi, T.J.A., Hayat, U., Roman, M., Abbas, H., Hussain, S. (2020b): Comparative study determining the impacts of broadleaved and Needle leaved forest harvesting on hydrology and water yield: State of knowledge and research outlook. -International Journal of Biological sciences. 16(2):231-240.

[12] Farooqi, T.J.A., Li, X., Yu, Z., Liu, S., Sun, O.J. (2020c): Reconciliation of research on forest carbon sequestration and water conservation. -Journal of Forestry Research. pp.1-8.

[13] Fioretto, A., Papa, S., Fuggi, A. (2003): Litter-fall and litter decomposition in a low Mediterranean shrubland. - Biology and Fertility of Soils 39(1): 37-44.

[14] Frey, S. D., Knorr, M., Parrent, J. L., Simpson, R. T. (2004): Chronic nitrogen enrichment affects the structure and function of the soil microbial community in temperate hardwood and pine forests. - Forest Ecology and Management 196(1): 159-171.

[15] Gartner, T. B., Cardon, Z. G. (2004): Decomposition dynamics in mixed-species leaf litter. - Oikos 104(2): 230-246.

[16] Handa, I. T., Aerts, R., Berendse, F., Berg, M. P., Bruder, A., Butenschoen, O., Chauvet, E., Gessner, M. O., Jabiol, J., Makkonen, M. (2014): Consequences of biodiversity loss for litter decomposition across biomes. - Nature 509(7499): 218. 
[17] Hättenschwiler, S., Tiunov, A. V., Scheu, S. (2005): Biodiversity and litter decomposition in terrestrial ecosystems. - - Annu. Rev. Ecol. Evol. Syst. 36: 191-218.

[18] Hobbie, S. E. (2000): Interactions between litter lignin and soil nitrogen availability during leaf litter decomposition in a Hawaiian montane forest. - Ecosystems 3: 484-494.

[19] Hobbie, S. E. (2005): Contrasting effects of substrate and fertilizer nitrogen on the early stages of litter decomposition. - Ecosystems 8(6): 644-656.

[20] Hobbie, S. E., Vitousek, P. M. (2000): Nutrient limitation of decomposition in Hawaiian forests. - Ecology 81(7): 1867-1877.

[21] Hoorens, B., Coomes, D., Aerts, R. (2010): Neighbour identity hardly affects littermixture effects on decomposition rates of New Zealand forest species. - Oecologia 162(2): 479-489.

[22] Hu, B., Yang, B., Pang, X., Bao, W., Tian, G. (2016): Responses of soil phosphorus fractions to gap size in a reforested spruce forest. - Geoderma 279: 61-69.

[23] Jeong, K. W., Kim, B. S., Ultra Jr, V. U., Lee, S. C. (2015): Effects of rhizosphere microorganisms and wood vinegar mixtures on rice growth and soil properties. - Korean Journal of Crop Science 60(3): 355-365.

[24] Kadota, M., Niimi, Y. (2004): Effects of charcoal with pyroligneous acid and barnyard manure on bedding plants. - Scientia Horticulturae 101(3): 327-332.

[25] Kim, S., Li, G., Han, S. H., Kim, H.-J., Kim, C., Lee, S.-T., Son, Y. (2018): Thinning affects microbial biomass without changing enzyme activity in the soil of Pinus densiflora Sieb. et Zucc. forests after 7 years. - Annals of Forest Science 75(1): 13.

[26] Koc, I., Yardim, E. N., Akca, M. O., Namli, A. (2018): impact of pesticides and wood vinegar, used in wheat agro-ecosystems, on the soil enzyme activities. - Fresenius Environmental Bulletin 27(4): 2442-2448.

[27] Kunhamu, T., Kumar, B., Viswanath, S. (2009): Does thinning affect litterfall, litter decomposition, and associated nutrient release in Acacia mangium stands of Kerala in peninsular India? - Canadian Journal of Forest Research 39(4): 792-801.

[28] Li, X., Farooqi, T.J.A., Jiang., C, Liu., S. Sun., O.J. (2019): Spatiotemporal variations in productivity and water use efficiency across a temperate forest landscape of Northeast China. -Forest Ecosystems. 6(1): p.22.

[29] Li, Q., Liu, Z. (2013): Effects of decomposed leaf litter mixtures from Platycladus orientalis and broadleaf tree species on soil properties. - Scandinavian Journal of Forest Research 28(7): 642-650.

[30] Li, W., Yu, W., Bai, L., Liu, H., Yang, D. (2016): Effects of nitrogen addition on the mixed litter decomposition in Stipa baicalensis steppe in Inner Mongolia. - American Journal of Plant Sciences 7(03): 547.

[31] Liu J. (2013): Effect of Tending Thinning and Pruning on Soil Quality of Larix PrincipisRupprechtii Plantation. - Beijing Forestry University, Beijing.

[32] Liu, P., Huang, J., Han, X., Sun, O. J., Zhou, Z. (2006): Differential responses of litter decomposition to increased soil nutrients and water between two contrasting grassland plant species of Inner Mongolia, China. - Applied Soil Ecology 34(2-3): 266-275.

[33] Liu, P., Huang, J., Sun, O. J., Han, X. (2010): Litter decomposition and nutrient release as affected by soil nitrogen availability and litter quality in a semiarid grassland ecosystem. - Oecologia 162(3): 771-780.

[34] Liu, X., Zhang, Y., Han, W., Tang, A., Shen, J., Cui, Z., Vitousek, P., Erisman, J. W., Goulding, K., Christie, P. (2013): Enhanced nitrogen deposition over China. - Nature 494(7438): 459.

[35] Mao, B., Yu, Z.-Y., Zeng, D.-H. (2015): Non-additive effects of species mixing on litter mass loss and chemical properties in a Mongolian pine plantation of Northeast China. Plant and Soil 396(1-2): 339-351.

[36] Matson, P., Lohse, K. A., Hall, S. J. (2002): The globalization of nitrogen deposition: consequences for terrestrial ecosystems. - AMBIO: A Journal of the Human Environment 31(2): 113-120. 
[37] Onyekwelu, J. C., Mosandl, R., Stimm, B. (2006): Productivity, site evaluation and state of nutrition of Gmelina arborea plantations in Oluwa and Omo forest reserves, Nigeria. Forest Ecology and Management 229(1-3): 214-227.

[38] Osono, T., Ono, Y., Takeda, H. (2003): Fungal ingrowth on forest floor and decomposing needle litter of Chamaecyparis obtusa in relation to resource availability and moisture condition. - Soil Biology and Biochemistry 35(11): 1423-1431.

[39] Pandey, R., Sharma, G., Tripathi, S., Singh, A. (2007): Litterfall, litter decomposition and nutrient dynamics in a subtropical natural oak forest and managed plantation in northeastern India. - Forest Ecology and Management 240(1-3): 96-104.

[40] Polyakova, O., Billor, N. (2007): Impact of deciduous tree species on litterfall quality, decomposition rates and nutrient circulation in pine stands. - Forest Ecology and Management 253(1-3): 11-18.

[41] Prescott, C. E. (2002): The influence of the forest canopy on nutrient cycling. - Tree Physiology 22(15-16): 1193-1200.

[42] Ruano, I., Rodríguez-García, E., Bravo, F. (2013): Effects of pre-commercial thinning on growth and reproduction in post-fire regeneration of Pinus halepensis Mill. - Annals of Forest Science 70(4): 357-366.

[43] Sinsabaugh, R., Carreiro, M., Repert, D. (2002): Allocation of extracellular enzymatic activity in relation to litter composition, $\mathrm{N}$ deposition, and mass loss. - Biogeochemistry 60(1): 1-24.

[44] Steiner, C., Das, K. C., Garcia, M., Förster, B., Zech, W. (2008): Charcoal and smoke extract stimulate the soil microbial community in a highly weathered xanthic Ferralsol. Pedobiologia 51(5-6): 359-366.

[45] Swift, M., Heal, O., Anderson, J. (1979): Decomposition in Terrestrial Ecosystems. Blackwell Scientific, Oxford.

[46] Tian, H., Cheng, X., Han, H., Jing, H., Liu, X., Li, Z. (2019): Seasonal variations and thinning effects on soil phosphorus fractions in Larix principis-rupprechtii Mayr. plantations. - Forests 10(2): 172.

[47] Tiilikkala, K., Setälä, H. (2009): Birch tar oil-a new innovations as biological plant protection product. - NWBC-2009. The 2nd Nordic Wood Biorefinery Conference. Finlandia Hall, Helsinki, Finland, September 2-4, 2009.

[48] Ullah, S., Muhammad, B., Amin, R., Abbas, H., Muneer, M. (2019): sensitivity of arbuscular mycorrhizal fungi in old-growth forests: direct effect on growth and soil carbon storage. - Applied Ecology and Environmental Research 17(6): 13749-13758.

[49] Velmurugan, N., Chun, S., Han, S., Lee, Y. (2009): Characterization of chikusaku-eki and mokusaku-eki and its inhibitory effect on sapstaining fungal growth in laboratory scale. - International Journal of Environmental Science \& Technology 6(1): 13-22.

[50] Vestgarden, L. (2001): Carbon and nitrogen turnover in the early stage of Scots pine (Pinus sylvestris L.) needle litter decomposition: effects of internal and external nitrogen. - Soil Biology and Biochemistry 33(4-5): 465-474.

[51] Wang, J., Zhang, D., Farooqi, T.J.A., Ma, L., Deng, Y. and Jia, Z. (2017): The olive (Olea europaea L.) industry in China: its status, opportunities and challenges. Agroforestry Systems 93(2):395-417.

[52] Wei, Q., Liu, G., Wei, X., Ma, X., Xu, D., Dong, R. (2009): Influence of wood vinegar as leaves fertilizer on yield and quality of celery. - Journal of China Agricultural University 14(1): 89-92.

[53] Wu, H., Lu, X., Yang, Q. (2007): Problems and countermeasures of decomposition bag method in the study of wetland litter decomposition. - Journal of Northeast Forestry University 35(2): 82-85.

[54] Yatagai, M., Nishimoto, M., Hori, K., Ohira, T., Shibata, A. (2002): Termiticidal activity of wood vinegar, its components and their homologues. - Journal of Wood Science 48(4): 338-342. 


$$
-4434 \text { - }
$$

[55] Yuan, J., Jose, S., Hu, Z., Pang, J., Hou, L., Zhang, S. (2018): Biometric and eddy covariance methods for examining the carbon balance of a Larix principis-rupprechtii forest in the Qinling Mountains, China. - Forests 9(2): 67. 